\title{
Aspects of reproduction and sexual dimorphism of Lygophis flavifrenatus (Dipsadidae: Xenodontinae)
}

\author{
Fernando Marques Quintela (1) \& Daniel Loebmann (1)
}

\begin{abstract}
Lygophis flavifrenatus Cope, 1862 is a terrestrial dispsadid distributed in subtropical Brazil, Paraguay, Uruguay, and Argentina. Herein, we present data on sexual dimorphism and reproductive biology of this very poorly studied species. A total of 108 specimens (55 females, 50 males, three hatchlings with unidentified sex) from Brazilian states of Rio Grande do Sul, Santa Catarina and Mato Grosso do Sul were analyzed. Sexual dimorphism by size, body dimensions (tail length, head length, head width) and a number of ventral and subcaudal scales is not well marked in the species. Mature females attain the greater size and have a higher number of ventral scales than mature males. Mature males, in turn, presented longer tail, longer and wider head and a higher number of subcaudal scales. Meanwhile, marked overlaps were observed in ranges of all body dimensions proportions and a number of ventral and subcaudal scales. Females attained sexual maturity at a greater size than males. The smallest mature female showed snout-vent length (SVL) $=402 \mathrm{~mm}$ while the smallest mature male presented SVL $=285 \mathrm{~mm}$. Females presented a seasonal reproductive cycle, with advanced stages (advanced development of secondary follicles and development of eggs) occurring in late winter and spring. Hatchlings were found in late summer. It is supposed that only one clutch is laid per cycle, considering that the great majority of secondary follicles found in females carrying eggs were irregular or lamellar shaped (possibly atresic). Clutch sizes varied from 6 to 12 eggs $($ mean $=8.2)$ and presented a tendency for positive correlation with progenitors SVL. The present study adds new information to the knowledge about the natural history of snakes from subtropical Neotropics.
\end{abstract}

KEYWORDS. Natural history, Neotropical region, Squamata, subtropical domain.

RESUMO. Aspectos da reprodução e dimorfismo sexual de Lygophis flavifrenatus (Dipsadidae: Xenodontinae). Lygophis flavifrenatus Cope, 1862 é um dipsadídeo terrestre distribuído pelo Brasil subtropical, Paraguai, Uruguai e Argentina. Apresentamos aqui dados sobre dimorfismo sexual e biologia reprodutiva desta espécie muito pouca estudada. Um total de 108 espécimes ( 55 fêmeas, 50 machos, três filhotes com sexo não identificado) procedentes dos estados brasileiros do Rio Grande do Sul, Santa Catarina e Mato Grosso do Sul foram analisados. Dimorfismo sexual por tamanho, dimensões corporais (tamanho da cauda, tamanho da cabeça, largura da cabeça) e número de escamas ventrais e subcaudais não é bem marcado na espécie. Fêmeas maduras atingem tamanhos maiores e possuem maior número de escamas ventrais do que os machos maduros. Machos maduros, por sua vez, apresentaram maior cauda, maior comprimento e largura de cabeça e maior número de escamas subcaudais. Entretanto, marcada sobreposição foi observada para os intervalos de todas as dimensões corporais e número de escamas ventrais e subcaudais. Fêmeas atingem a maturidade sexual com maior tamanho do que machos. A menor fêmea madura apresentou comprimento rostro-cloacal (SVL) $=402$ mm, enquanto que o menor macho maduro apresentou SVL $=285 \mathrm{~mm}$. As fêmeas apresentaram um ciclo reprodutivo sazonal, com os estágios avançados (desenvolvimento avançado de folículos secundários e desenvolvimento de ovos) ocorrendo no final do inverno e primavera. Filhotes recém-eclodidos foram encontrados no fim do verão. É suposto que apenas uma desova ocorra por ciclo, considerando-se que a grande maioria dos folículos secundários encontrados em fêmeas ovadas apresentou forma irregular ou lamelar (possivelmente atrésicos). $\mathrm{O}$ tamanho da prole variou de 6 a 12 ovos (média $=8,2)$ e apresentou uma tendência à correlação positiva com o SVL das progenitoras. O presente estudo adiciona novas informações ao conhecimento sobre a história natural de serpentes procedentes do Neotrópico subtropical.

PALAVRAS-CHAVE. História natural, Região Neotropical, Squamata, domínio subtropical.

Information on aspects of natural history of snakes is crucial for understanding on ecological and evolutionary processes of species and communities (GREENE, 1993). Among the several aspects of natural history, data on the reproductive biology are especially essential, considering its importance for the adoption of strategies for the species conservation (SHINE \& BonNET, 2009; AlMEIDA-SANTOS et al., 2014). Once scarce, studies on the reproductive aspects of Neotropical snakes have received a substantial increment in the past decades (ALMEIDASANTOS et al., 2014), which included relevant investigations on species or populations occurring in subtropical climatic domains (HARTMANN et al., 2004; AgUIAR \& Di-BERnARDO, 2005; BaLESTRIN \& Di-BERNARdo, 2005; LeITE et al., 2009; Zanella \& Cechin, 2010; Oliveira et al., 2011; Mesquita et al., 2013; Panzera \& Maneyro, 2013; Rebelato et al., 2016; Loebens et al., 2017; Quintela et al., 2017). These studies revealed a predominant pattern of seasonal female reproductive cycle (restricted to the warmer period of the year) and marked sexual dimorphism, where females attain larger body sizes and males have tails comparatively larger. 
The genus Lygophis currently comprises eight species of small to medium-sized slender dipsadids, which is distributed from Panamá to Central-Eastern Argentina (UETZ \& HošEK, 2018). Previously included in genus Liophis (currently Erythrolamprus), species of Lygophis differ from those ones by the presence of longitudinal well-marked dorsal stripes, reduced optic foramen, besides of hemipenial morphology (ZAHER et al., 2009). The "Fronted Ground Snake" Lygophis flavifrenatus Cope, 1862 is a typical subtropical species, distributed in Brazilian states of São Paulo, Mato Grosso do Sul, Paraná, Santa Catarina, and the Rio Grande do Sul, southeastern Paraguay, Uruguay, and northeastern Argentine (Michaud \& DiXON, 1987; GIRAUDO et al., 2001; UETZ \& HoŠEK, 2018). Typically terrestrial, it can be found mainly in open habitats such as grasslands and swamps. (QUiNTELA \& LoEBMANN, 2009).

Lygophis flavifrenatus has been considered an uncommon species along its distributional range (SMITH, 2006; GHIzONI-JR et al., 2009; QUintela \& LoEBMANN, 2009), which is a possible reason why data on its natural history are extremely scarce. There are few and scattered data on diet (CARREIRA-VIDAL, 2002), litter size (AMARAL, 1977; ACHAVAL \& OLMOS, 2003), morphometrics and folidosis (Michaud \& Dixon, 1987; Giraudo, 2001), based on analysis of few specimens. Previous data on reproductive traits of $L$. flavifrenatus are limited to observation on clutch size (Amaral, 1977; Achaval \& Olmos, 2003), and Lygophis anomalus (Günther, 1858) is the only Lygophis species further investigated for reproduction (PANZERA \& Maneyro, 2013; Sivan et al., 2016). Lygophis anomalus females presented seasonal reproductive cycle, clutch size averaging 7.37 eggs, possibly lay multiple clutches during one reproductive season, and reach sexual maturity with a larger size than males (PANZERA \& MANEYRO, 2013). Mature females and males of $L$. anomalus also differ significantly in body size and tail length (PANZera \& MANEYro, 2013). In relation to L. flavifrenatus, there are no available data on sexual dimorphism and life-history traits such as size at sexual maturity, reproductive cycle, and size of newborns.

In the present study, we accessed and analyzed specimens of Lygophis flavifrenatus from Pampa and Atlantic Forest Domains in subtropical Brazil. We provide data on morphometrics, sexual dimorphism, and aspects of reproductive biology, aiming to contribute to the knowledge on this poorly investigated species as well as to add data for the understanding of reproductive/evolutionary patterns occurring in Neotropical snakes. Considering the patterns recurrently found in the aforementioned studies, we expect that $L$. flavifrenatus females will show a seasonal reproductive cycle and larger size than males at sexual maturity. We also expect to evidence the sexual dimorphism in relation to tail length, with males showing tail proportionally longer.

\section{MATERIAL AND METHODS}

We examined specimens deposited in the herpetological collections of Universidade Federal do Rio
Grande (CHFURG) and Pontifícia Universidade Católica do Rio Grande do Sul (MCP), collected between 1968 and 2016 in 16 municipalities located in the Brazilian states of Mato Grosso do Sul, Santa Catarina and the Rio


$52^{\circ} 32^{\prime} 25^{\prime}$ 'W) (Appendix I). Collection sites are inserted in biomes Atlantic Forest and Pampa (IBGE, 2018). The annual average temperature is $18.6^{\circ} \mathrm{C}$ and the monthly averages of minimum (June-July) and maximum (January) temperatures are 13.9 and $19.5^{\circ} \mathrm{C}$, respectively. Altitude range from 1 to $1,028 \mathrm{~m}$ (a.s.l.) and the annual average precipitation range from 1,205 to 2,109 mm (Climate-Data, 2018).

The following data were taken from each specimen (linear measurements in $\mathrm{mm}$ ): data of collection, locality, sex, condition of sexual maturity, snout-vent length (SVL), tail length (TL), total length (TTL, the sum of SVL and TL), head length (HL) and head width (HW), number of ventral scales (VS), number of subcaudal scales (SS), ratio of TL to SVL (TL/SVL), ratio of HL to SVL (HL/SVL), ratio of $\mathrm{HW}$ to SVL (HW/SVL). The sex of each specimen was determined with the verification of the presence or absence of hemipenis via the subcaudal incision. Females were considered sexually mature when showing at least one of the following characteristics: secondary follicles; oviductal eggs or embryos; folded oviducts, indicating recent oviposition (MesQuita et al., 2013). Males were considered sexually mature when presenting coiled and opaque ductus deferens, indicating the presence of sperm (SHINE, 1977; AlmeidA-SAntos et al., 2014). The sexual size dimorphism index (SSD) was calculated as the mean SVL of the larger sex divided by the mean SVL of the smaller sex, minus one. Negative values indicate that males are larger than females (SHINE, 1994). The existence of significant sexual dimorphism in SVL, TTL, VS, and SS was examined through a Student's $t$-test (significance $p<0.05$ ). The existence of significant sexual dimorphism in TL, HL, and HW was examined through a one-way ANCOVA, using SVL as the independent variable (significance $p<0.05$ ) (SiqueIRA et al., 2013). This procedure was adopted with the objective of minimizing the effect of body size on the analyzes. Only mature specimens were used for SVL, TTL, TL, HL and HW comparisons while mature and immature specimens were pooled for VS and SS comparisons. Specimens with damaged venter, tail or head were excluded from analysis.

The following data were taken from females: 1) a total number of ovarian follicles; 2) a total number of secondary follicles (follicles in secondary vitellogenesis); 3 ) largest diameter of the largest secondary follicle; 4) a total number of oviductal eggs; 5) largest diameter of the largest egg. The initial diameter of secondary follicles was determined based on coloration; primary follicles differ conspicuously from secondary follicles due to their darker yellow coloration (see Almeida-Santos et al., 2014). The largest diameter of secondary follicles and eggs of females was plotted in an annual temporal axis aiming to obtain data on female reproductive cycle (MesQuita et al., 2013; AlMEIDA-SANTOS et al., 2014). Fecundity was determined by the number of 
oviductal eggs (real fecundity) and a number of secondary follicles (potential fecundity) (Mesquita et al., 2013). The relationship between female SVL and real fecundity was examined through simple linear regression analysis (SIQUEIRA et al., 2013). Statistical tests were performed in software PAST v.3.20 (HAMMER et al., 2001).

\section{RESULTS AND DISCUSSION}

A total of 108 specimens (55 females and 50 males) were analyzed. It was not possible to identify the sex of three hatchlings. Although we observed an overlap of values between the sexes, the males presented higher mean values for all body ratios (TL/SVL, HL/SVL and HW/SVL) (Tab. 1). Significant differences between sexes were found for the variables SVL, TTL, TL, HL, VS and SS (Tab. II). Females showed a higher number of ventral scales (VS) while males presented a higher number of subcaudal scales (SS), but overlapped ranges were observed for both of these characters (Tab. II). The positive value of the sexual size dimorphism index $(\mathrm{SSD}=0.206)$ indicated that females are larger than males.

The smallest male with coiled/opaque ductus deferens (mature male) presented SVL $=285 \mathrm{~mm}$. Reproductive males $(n=28)$ corresponded to $50 \%$ of the male sample. The smallest follicle showing characteristics of secondary vitellogenesis presented the largest diameter of $5.93 \mathrm{~mm}$. The smallest female carrying secondary follicles (mature female) presented SVL $=402 \mathrm{~mm}$ while the smallest female carrying eggs showed SVL $=409 \mathrm{~mm}$. Reproductive females $(n=23)$ corresponded to $41.8 \%$ of the female sample. The smallest female carrying primary follicles presented $\mathrm{SVL}=$ $202 \mathrm{~mm}$. Primary follicles were found in females collected in all seasons. Secondary follicles were found in 13 females collected from May (middle autumn) to December (late spring). Eggs were found in seven females collected in October and November (early and middle spring) (Fig. 1). Two hatchlings (MCP 14350, SVL= 123 mm; MCP 14351, $\mathrm{SVL}=100 \mathrm{~mm}$ ) retained information about their birth in captive, occurred on March 13 (late summer), but lacked information on the date of their mother egg-laying. A third hatchling specimen with a marked umbilical scar and similar size (MCP 6859, SVL = 101) was collected on February 25 (late summer). The potential fecundity varied from 1 to 13 ( 1 to 5 in female carrying eggs $[X=2.5 ; \mathrm{n}=5], 3$ to 13 in females without eggs $[X=7.4 ; \mathrm{n}=7])$. The real fecundity varied from 6 to $12(X=8.2 ; \mathrm{n}=7)$. Five of the six females carrying eggs also presented secondary follicles, but the great majority of these follicles were lamellar or irregular shaped, possibly atretic. The result of the simple linear regression analysis $(r=0.74 ; \mathrm{p}=0.086 ; \mathrm{n}=7)$ indicates a tendency for positive correlation between female SVL and real fecundity.

Females of Lygophis flavifrenatus attain greater total length than males, as well as the majority of dipsadids investigated so far (e.g. Aguiar \& Di-Bernardo, 2005; Balestrin \& Di-Bernardo, 2005; López \& Giraudo, 2008, Pizzatto et al., 2008; Zanella \& CeChin, 2010; Mesquita et al., 2013; PANZERA \& MANeyro, 2013; Quintela et al., 2017). Body size in females is associated with fecundity so that a larger body can accommodate a larger offspring (SHINE, 1994). In addition to total length, significant differences between the sexes of L. flavifrenatus were found for all the other characters except head width (Tab. I). Nevertheless, the superimposed values of the tail and head

Tab. I. Values of ratio of tail length to snout-vent length (TL/SVL), ratio of head length to snout-vent length (HL/SVL) and ratio of head width to snoutvent length (HW/SVL) for males and females of Lygophis flavifrenatus Cope, 1862 from Brazil. Values are presented as mean \pm one standard deviation (range); $\mathrm{n}=$ number of analyzed specimens.

\begin{tabular}{lcc}
\hline Ratio & Females & Males \\
\hline TL/SVL & $0.372 \pm 0.025(0.339-0.452) \mathrm{n}=18$ & $0.405 \pm 0.016(0.367-0.447) \mathrm{n}=24$ \\
HL/SVL & $0.037 \pm 0.002(0.033-0.041) \mathrm{n}=22$ & $0.040 \pm 0.002(0.036-0.044) \mathrm{n}=27$ \\
HW/SVL & $0.018 \pm 0.002(0.015-0.021) \mathrm{n}=22$ & $0.020 \pm 0.001(0.016-0.027) \mathrm{n}=27$ \\
\hline
\end{tabular}

Tab. II. Summary statistics (mean \pm one standard deviation (range); $\mathrm{n}=$ number of analyzed specimens) and values of statistical tests for the variables analyzed for sexual dimorphism in Lygophis flavifrenatus Cope, 1862 from Brazil. Significant differences are indicated in bold.

\begin{tabular}{|c|c|c|c|c|}
\hline Variable & Females & Males & Statistical test & $\mathrm{p}$ values \\
\hline SVL & $\begin{array}{c}495.26 \pm 61.53(402-627) \\
n=23\end{array}$ & $\begin{array}{c}375.34 \pm 47.87(285-460) \\
n=28\end{array}$ & $t=7.813$ & $3.683^{\mathrm{E}-10}$ \\
\hline TTL & $\begin{array}{c}649.77 \pm 62.74(553-746) \\
n=18\end{array}$ & $\begin{array}{c}520.71 \pm 66.99(402-629) \\
n=24\end{array}$ & $t=6.346$ & $\mathbf{1 . 5 3 8}{ }^{\mathrm{E}-07}$ \\
\hline TL & $\begin{array}{c}179.00 \pm 18.16(146-206) \\
\mathrm{n}=18\end{array}$ & $\begin{array}{c}150.16 \pm 18.83(117-174) \\
n=24\end{array}$ & $F=4.532$ & 0.039 \\
\hline HL & $\begin{array}{c}18.15 \pm 1.77(14.98- \\
21.65) \mathrm{n}=22\end{array}$ & $\begin{array}{c}15.04 \pm 1.59(12.63- \\
18.46) \mathrm{n}=27\end{array}$ & $F=36.73$ & $\mathbf{2 . 3 4 9} 9^{\mathrm{E}-07}$ \\
\hline HW & $\begin{array}{c}8.90 \pm 1.05(7.19-10.85) \\
n=22\end{array}$ & $\begin{array}{c}7.44 \pm 0.87(5.66-9.53) \\
n=27\end{array}$ & $F=0.023$ & 0.878 \\
\hline VS & $164 \pm 4(155-179) n=55$ & $156 \pm 4(147-167) n=50$ & $t=9.214$ & $4.0418^{\mathrm{E}-15}$ \\
\hline SS & $81 \pm 3(75-92) n=46$ & $87 \pm 4(78-99) n=41$ & $t=6.081$ & $\mathbf{3 . 2 8 0 5}{ }^{\mathrm{E}-08}$ \\
\hline
\end{tabular}




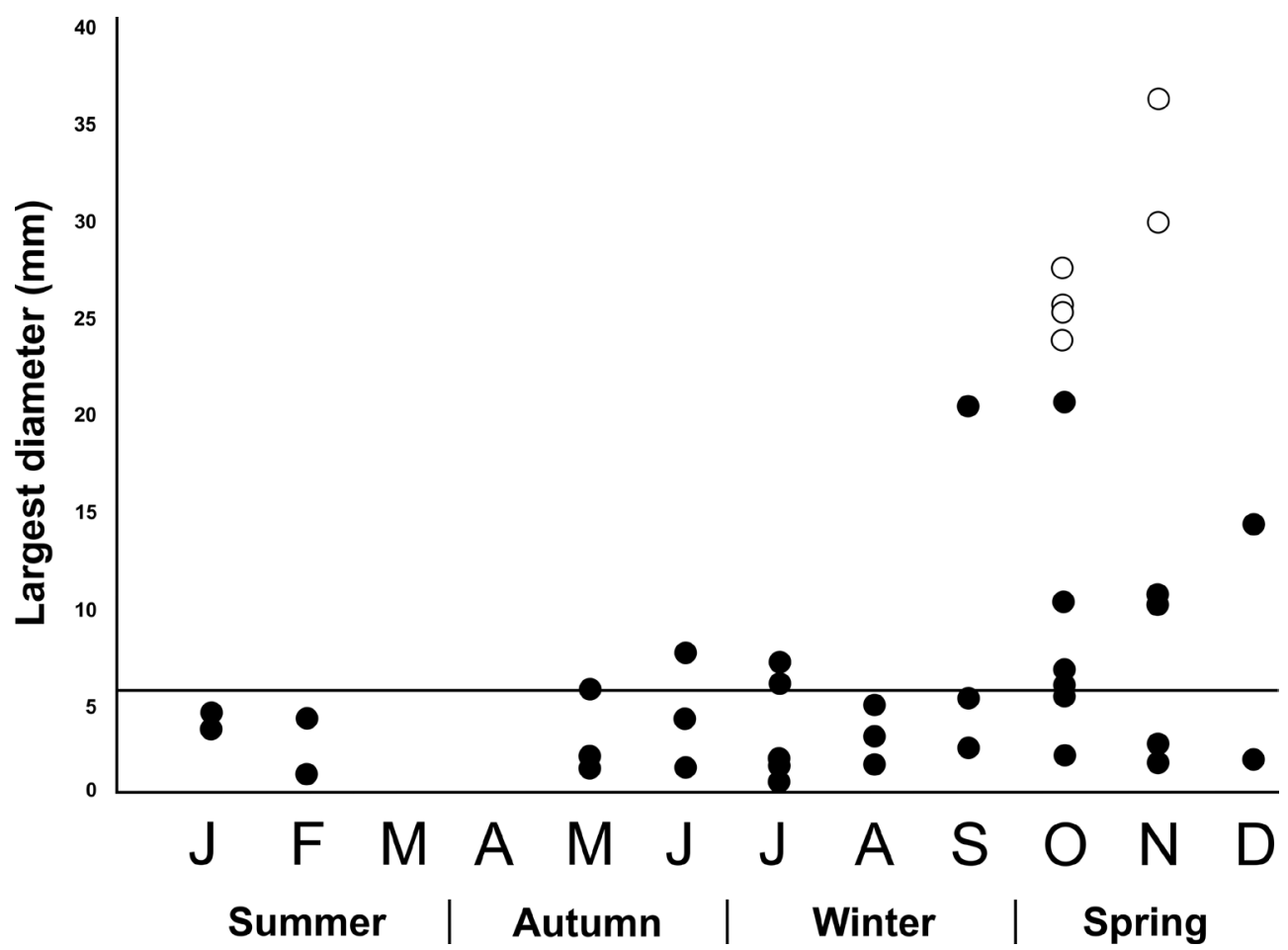

Fig. 1. Monthly variation in largest diameter (in millimeters) of the largest follicles (black circles) and eggs (white circles) of Lygophis flavifrenatus Cope, 1862 from Brazil. The horizontal line indicates the size from which follicles were considered as being in secondary vitellogenesis (secondary follicles).

proportions in relation to body size (TL/SVL, HL/SVL, and $\mathrm{HW} / \mathrm{SVL}$ ), as well as the number of ventral and subcaudal scales, makes these characters not absolutely dimorphic. Considering the mean values, males have a comparatively longer tail (TL/SVL) and a larger and wider head (HL/ SVL and HW/SVL, respectively; Table 1). However, it is notable that the maximum value for the TL/SVL ratio (0.452) was recorded for a female specimen (Tab. I). Values of TL/ SVL ratios calculated from minimum and maximum TL and SVL measures of L. flavifrenatus from northeastern Argentina (GIRAUDO, 2001) were similar between sexes, but males retained the highest proportion (males: $0.340-$ 0.366 ; females: $0.322-0.346$ ). Minimum and maximum TL/SVL ratios of Argentine specimens were also lower than those recorded in our sample. Although the limited samples do not allow further comparisons and conclusions, it is possible the existence of geographic variation in this character, as already observed for the sympatric dipsadidae Erythrolamprus poecilogyrus sublineatus (Cope, 1860) (QUINTELA et al., 2017). In relation to head dimensions (HL, HW), females presented larger length and width although significant differences were found only for the first (Tab. II). It is known that sexual dimorphism in size and shape of the head in snakes can be related to combat behavior, divergence in diet or non-adaptative allometry (MeIK et al., 2012). Once male-male combat is unknown for L. flavifrenatus or any other Lygophis species, it is possible that differences in head proportions are related to dietary divergences between sexes (males preying on relatively larger prey), as a mechanism for the reduction of intraspecific competition for food resources, or may even constitute a result of non-adaptive allometry.
The clutch size (real fecundity) herein reported for $L$. flavifrenatus had a broader range than previous observations for the species (8 to 12; AMARAL, 1977; ACHAVAL \& Olmos, 2003 ) and was exactly the same found for $L$. anomalus (Panzera \& Maneyro, 2013). A positive correlation between female SVL and clutch size was also detected for L. anomalus (PANZERA \& MANEYRo, 2013). However, when potential fecundity is considered, a much broader range was observed in L. anomalus ( 1 to 27; PANZERA \& MANEYRO, 2013), emphasizing that the minimum size of secondary follicles was the same for both species $(6 \mathrm{~mm})$. Therefore, L. flavifrenatus and L. anomalus share some similarities concerning the female reproductive biology, which includes the cyclicity pattern, clutch size, relationship between the size of female body and clutch size, and the size of the follicle at the beginning of secondary vitellogenesis. This is not surprising, considering that phylogenetic conservatism in reproductive traits is pronounced in Xenodontinae snakes (BELLINI et al., 2017). Moreover, the two species are sympatric in a great part of their distribution (GIRAUDO, 2001), sharing environmental conditions (climate, habitats) and even feeding habits (CARREIRA \& MANEYRO, 2013), which may reinforce such similarities if environmental factors also contribute to shaping the reproductive patterns.

The annual profile of the largest follicles and eggs indicates a seasonal reproductive cycle for Lygophis flavifrenatus females. Vitellogenesis begins in autumn and extends until spring when copulation and development of eggs take place. Copulation occurs at the end of winter, considering that eggs were found already in early spring (October). The finding of mature females euthanized in 
summer (January and February) showing folded oviducts and carrying only primary follicles associated to the information on date of hatchlings birth and collection (late February and March) indicates that egg-laying occurs during middle/ late spring and early summer, seeing that period of egg incubation for other xenodontines in the region varied from 55 to 84 days (J. G. Frota, unpubl. data; F. Bonfiglio, unpubl. data; G. M. Funk-Pontes, unpubl. data). Once cold temperatures represent a limiting factor mainly for egg incubation (HUBERT, 1985), the seasonal cycle with the advanced stages restricted to warmer seasons was expected. This pattern corroborates with the female cycle observed for congeneric Lygophis anomalus (PANZERA \& MANEYRO, 2013), as well as subtropical populations of other dipsadid species (Aguiar \& Di-Bernardo, 2005; BALESTRIN \& DiBernardo, 2005; LóPez \& Giraudo, 2008; Zanella \& CeChin, 2010; Oliveira et al., 2011; MesQuita et al. 2013; Rebelato et al. 2016; Quintela et al., 2017; J. G. Frota, unpubl. data; F. Bonfiglio, unpubl. data; G. M. Funk-Pontes, unpubl. data). The preponderant occurrence of irregularshaped secondary follicles (probably atretic) in females carrying eggs also indicates that a single egg-laying take place during a cycle. This finding contrasts L. anomalus, supposed to lay multiple clutches during a cycle (PANZERA \& MANeYro, 2013).

This is the first study to bring further information on sexual dimorphism and reproduction of Lygophis flavifrenatus, adding to the knowledge on the biology of Neotropical snakes. The new data herein presented support the predominant pattern of female reproductive cycle found so far for dipsadids from subtropical domains of South America. The similarities of female reproduction traits with the congenus $L$. anomalus indicate the phylogenetic conservatism, although environmental driving forces may not be disconsidered. Ongoing studies on morphometrics and histology of male gonads and ductus deferens will soon provide data on male reproductive cycle, bringing an integrative perspective on the reproductive biology of this poorly known species.

Acknowledgments. We are thankful to Glaucia M. Funk Pontes for access to MCP specimens; Victor H. Teixeira, Omar M. Entiauspe, Rafael A. Porciuncula, Ruth A. Regnet and Felipe Caseiro for help in fieldwork; CAPES (Coordenação de Aperfeiçoamento de Pessoal de Nível Superior) for postdoctoral fellowship granted to FMQ; CNPq (Conselho Nacional de Pesquisa e Desenvolvimento) for research grant to DL (proc. $310651 / 2017-4)$.

\section{REFERENCES}

Achaval, F. \& Olmos, A. 2003. Anfibios y reptiles del Uruguay. 2ed. Montevideo, Graphis. 136p.

AgUiar, L. F. S. \& Di-Bernardo, M. 2005. Reproduction of the water snake Helicops infrataeniatus (Colubridae) in southern Brazil. AmphibiaReptilia 26(4):527-533.

Almeida-Santos, S. M.; Braz, H. B. P.; Santos, L. C.; Barros, V. A.; Rojas, C. A. \& Kasperoviczus, K. N. 2014. Biologia reprodutiva de serpentes: recomendações para a coleta e análise de dados. Herpetologia Brasileira 3(1):14-24.
Amaral, A. 1977. Serpentes do Brasil. Iconografia Colorida. Brasília, Universidade de São Paulo. 246p.

Balestrin, R. L. \& Di-Bernardo, M. 2005. Reproductive biology of Atractus reticulatus (Boulanger, 1885) (Serpentes: Colubridae) in Southern Brazil. Herpetological Journal 15:195-199.

Bellini, G. P.; ArZamendia, V. \& Giraudo, A. R. 2017. Is xenodontine snake reproduction shaped by ancestry, more than by ecology? Ecology and Evolution 7(1):263-271.

Carreira, S. \& Maneyro, R. 2013. Guia de reptiles del Uruguay. Montevideo, Ediciones de la fuga. 288p.

CARreira-Vidal, S. 2002. Alimentación de los ofidios de Uruguay. Barcelona, Associación Herpetológica Española. 127p.

Climate-Data, 2018. Dados climáticos para cidades mundiais. Available at $<$ https://pt.climate-data.org $>$. Accessed on 23 June 2018.

Ghizoni-Jr.; I. R., Kunz, T. S.; Cherem, J. J. \& Bérnils, R. S. 2009. Registros notáveis de répteis de áreas abertas naturais do planalto e litoral do Estado de Santa Catarina, sul do Brasil. Biotemas 22(3): 129141.

Giraudo, A. R. 2001. Serpientes de la selva Paranaense y del Chaco húmedo. Buenos Aires, L.O.L.A. 328p.

GreENE, H.W. 1993. What's good about natural history. Herpetological Natural History 1:3.

Hammer, O.; Harper, D. A. T. \& Rian, P. D. 2001. PAST: Palaeonthological statistics software package for education and data analysis. Paleontologia Electronica 4(1):1-9.

Hartmann, M. T.; Marques, O. A.V. \& Almeida-Santos, S. M. 2004. Reproductive biology of the Southern Brazilian pitviper Bothrops neuwiedi pubescens (Serpentes, Viperidae). Amphibia-Reptilia 25:77-85.

Hubert., J. 1985. Embryology of the squamata. In: Gans, C. \& Billet, F. eds. Biology of the Reptilia 15. New York, Chichester, Brisbane, Toronto, and Singapore, Wiley and Sons, p. 1-55.

IBGE - Instituto Brasileiro de Geografia e Estatística. 2018. Mapas temáticos. Available at $<$ http://www. mapas.ibge.gov.br/tematicos. $\mathrm{html}>$. Accessed on 14 July 2018.

Leite, P. T.; Nunes, S. F.; Kaefer, I. L. \& Cechin, S. Z. 2009. Reproductive biology of the swamp racer Mastigodryas bifossatus (Serpentes: Colubridae) in subtropical Brazil. Zoologia 26(1):12-18.

Loebens, L.; Rojas, C. A.; Almeida-Santos, S. M. \& Cechin, S. Z. 2017. Reproductive biology of Philodryas patagoniensis (Snakes: Dipsadidae) in south Brazil: Female reproductive cycle. Acta Zoologica 99(2): 105-114.

LóPez, M. S. \& Giraudo, A. R. 2008. Ecology of the snake Philodryas patagoniensis (Serpentes, Colubridae) from Northeast Argentina. Journal of Herpetology 42(3):474-480.

Mesquita, P. C. M. D.; SÁ-Polidoro, G. L. \& Cechin, S. Z. 2013. Reproductive biology of Philodryas olfersii (Serpentes, Colubridae) in a subtropical region of Brazil. Herpetological Journal 23(1):39-44.

Meik, J. M.; Setser, K.; Mociño-Deloya, E. \& Lawing, A. M. 2012. Sexual differences in head form and diet in a population of Mexican lance-headed rattlesnakes, Crotalus polystictus. Biological Journal of the Linnean Society 106(3):633-640.

Michaud, E. J. \& Dixon, J. R. 1987. Taxonomic revision of the Liophis lineatus complex (Reptilia: Colubridae) of Central and South America. Milwaukee Public Museum Contributions in Biology and Geology 71:1-26.

Oliveira, R. B.; Funk-Pontes, G. M.; Maciel, A. P.; Gomes, L. R. \& DiBernardo, M. 2011. Reproduction of Xenodon dorbignyi on the north coast of Rio Grande do Sul, Brazil. Herpetological Journal 21:219-225.

Panzera, A. \& Maneyro, R. 2013. Reproductive biology of the snake Liophis anomalus (Günther, 1858, Dipsadidae, Xenodontinae). Herpetological Journal 23:81-87.

Pizzato, L.; Cantor, M.; Oliveira, J. L.; Marques, O. A. V.; CaPovilla, V. $\&$ MARTINs, M. 2008. Reproductive ecology of Dipsadine snakes, with emphasis on South American species. Herpetologica 64(2):168-179.

Quintela, F. M. \& Loebmann, D. 2009. Guia ilustrado: os répteis da região costeira do extremo sul do Brasil. Pelotas, USEB. 82p.

Quintela, F. M.; Marques, W. C. \& Loebmann, D. 2017. Reproductive biology of the Green Ground Snake Erythrolamprus poecilogyrus 
sublineatus (Serpentes: Dipsadidae) in Subtropical Brazil. Anais da Academia Brasileira de Ciências 89(3):2189-2197.

Rebelato, M. M.; Pontes, G. M. F. \& Tozetti, A. M. 2016. Reproductive biology of Thamnodynastes hypoconia (Serpentes: Dipsadidae) in Brazilian subtemperate wetlands. Anais da Academia Brasileira de Ciências 88:1699-1709.

SHINE, R. 1994. Sexual dimorphism in snakes revised. Copeia 1994:326-346.

SHINe, R. 1977. Reproduction in Australian elapid snakes. I. Testicular cycles and mating seasons. Australian Journal of Zoology 25:647-653.

SHine, R. \& BonNET, X. 2009. Linking reproductive biology to conservation objectives. In: Mullin, S. J. \& Siegel, R. A. eds. Snakes: Ecology and Conservation. Ithaca, Cornell University Press, p. 172-200.

Siqueira, D. M.; Nascimento, L. P.; Montingelli, G. G. \& Santos-Costa, M. C. 2013. Geographical variation in the reproduction and sexual dimorphism of the Boddaert's tropical racer, Mastigodryas boddaerti (Serpentes: Colubridae). Zoologia 30(5):475-481.
Sivan, J.; Panzera, A. \& Maneyro, R. 2016. Male Reproductive Cycle of a Neotropical Snake, Lygophis anomalus (Dipsadidae), in a Temperate Geographic Distribution. South American Journal of Herpetology 11(2):114-118.

Smith, P. 2006. Fauna Paraguay. Available at $<$ http://www.faunaparaguay. com>. Accessed on 19 July 2018.

Uetz, P.; Freed, P. \& Hošek, J. 2018. The Reptile Database. Available at $<$ http://www.reptile-database.org $>$. Accessed on 23 July 2018.

Zaher, H.; Grazziotin, F. G.; Cadle, J. E.; Murphy, R. W.; MouraLeite, J. C. \& Bonatto, S. L. 2009. Molecular phylogeny of advanced snakes (Serpentes, Caenophidia) with an emphasis on South American Xenodontines: a revised classification and descriptions of new taxa. Papéis Avulsos de Zoologia 49(11):115-153.

ZANELlA, N. \& CECHIN, S. Z. 2010. Reproductive biology of Echinanthera cyanopleura (Serpentes: Dipsadidae) in southern Brazil. Zoologia 27(1):30-34.

Appendix I. Specimens of Lygophis flavifrenatus Cope, 1862 analyzed and vouchered in herpetological collections of Universidade Federal de Rio Grande (CHFURG) and Museu de Ciências e Tecnologia da Pontifícia Universidade Católica do Rio Grande do Sul (MCP).

BRAZIL, Mato Grosso do Sul: Amambaí (MCP 16357); Santa Catarina: Fraiburgo (MCP 16355, 16356), Campo Belo do Sul (MCP 12097), Lages (MCP 18580); Rio Grande do Sul: São Francisco de Paula (MCP 7777), Arroio do Sal (MCP 4347, 4384, 5247, 11296), Capão da Canoa (MCP 6759, 6760), Balneário Pinhal (MCP 8586, 8587, 11832, 13122, CHFURG 5405), General Câmara (MCP 4232), Canoas (MCP 110), Porto Alegre (MCP 3182 , 3277, 6859, 14350, 14351), Cacequi (MCP 18736), Cachoeira do Sul (MCP 6184), Palmares do Sul (MCP 5248, 10650, 10651, 10998, 11187, 11188, 11196), Tavares (MCP 4219), Lavras do Sul (MCP 18831), São Gabriel (MCP 18832), Rio Grande, Senandes (CHFURG 813, 1029, 1253), Bolaxa (CHFURG 3161), Barra (CHFURG 1694, 1701, 1702, 1835, 1857, 1867, 1859, 1877, 1989, 3082, 3111, 3113, 3330, 3331, 3332, 3437, 4442, 4573, 4697, 4786, 4787, 4815, 4898, 4899, 4900, 4983, 4991, 4996, 4997, 5057, 5058, 5059, 5060, 5064, 5200, 5220, 5223, 5236, 5274, 5282, 5300, 5301, $5308,5321,5322,5335,5375,5377,5381,5383,5384,5385,5386,5387,5388,5389,5391,5392,5393,5396,5402,5403,5580,5581,5714,5976)$, Parque São Pedro (CHFURG 872), Taim (CHFURG 1420). 